\title{
Geology and Geothermal Resources of the Rexburg Area, Eastern Idaho
}

by

\author{
Harold J. Prostka and Glenn F. Embree \\ U.S. Geological Survey, Denver, Colorado
}

Open-File Report 78-1009

1978

This report is preliminary and has not been edited or reviewed for conformity with U.S. Geological Survey standards. 
Introduction

This report is a brief description of major Cenozoic geologic features of the Rexburg area and a discussion of their geothermal significance. The study area, identified as having geothermal potential, is approximately circular, about $55 \mathrm{~km}$ across, and centered on the town of Rexburg (fig. 1). It is roughly coextensive with a complex of about eight calderas of Pliocene age, here named the Rexburg caldera complex. These calderas were the source of several major rhyolitic volcanic deposits present along the southeast margin of the eastern Snake River Plain.

The geology of this area was previously mapped in reconnaissance (Prostka ard Hackman, 1974) and much of it was remapped in detail in 1977 because of its recognized geothermal potential (pl. 1).

\section{Methods of Study}

Overlapping and nested calderas form fault-bounded, closed basins filled with highly permeable materials that may make excellent geothermal reservoirs. Figure 2 is a sketch map of the main features of the Rexburg caldera complex as interpreted from preliminary evidence. This interpretive map is tentative, to be tested and modified as necessary. It is based on detailed and reconnaissance geologic mapping, interpretation of subtle topographic features shown on 7.5-minute topographic quadrangle maps, photogeologic interpretation of topographic and geologic features, and preliminary studies of facies and directions of flow of the volcanic units, primarily by measurement of size and orientations of elongate pumice fragments in ash flow tuffs.

Because most of the Pliocene rock units and major structural features are concealed beneath an extensive blanket of Pleistocene extrusive rocks and loess, some highly interpretive methods have been used to locate the boundaries of the calderas and faults shown in figure 2. Subtle topographic scarps and breaks in slope were detected by enhancing the expression of these features on standard topographic quadrangles. This process involves generalizing contour lines at selected intervals by removing minor irregularities such as the effects of small stream valleys and gullies. It is basically a modification of the form line concept, which emphasizes the general form of a topographic or structural surface and eliminates minor irregularities. The major features detected by this technique, combined with mapped structural features and major arcuate and linear drainage segments, are shown on an interpretive geologic map (p1. 2). Figure 2 was derived from this map. Evidence for the individual calderas shown on figure 2 is discussed in more detail below. 


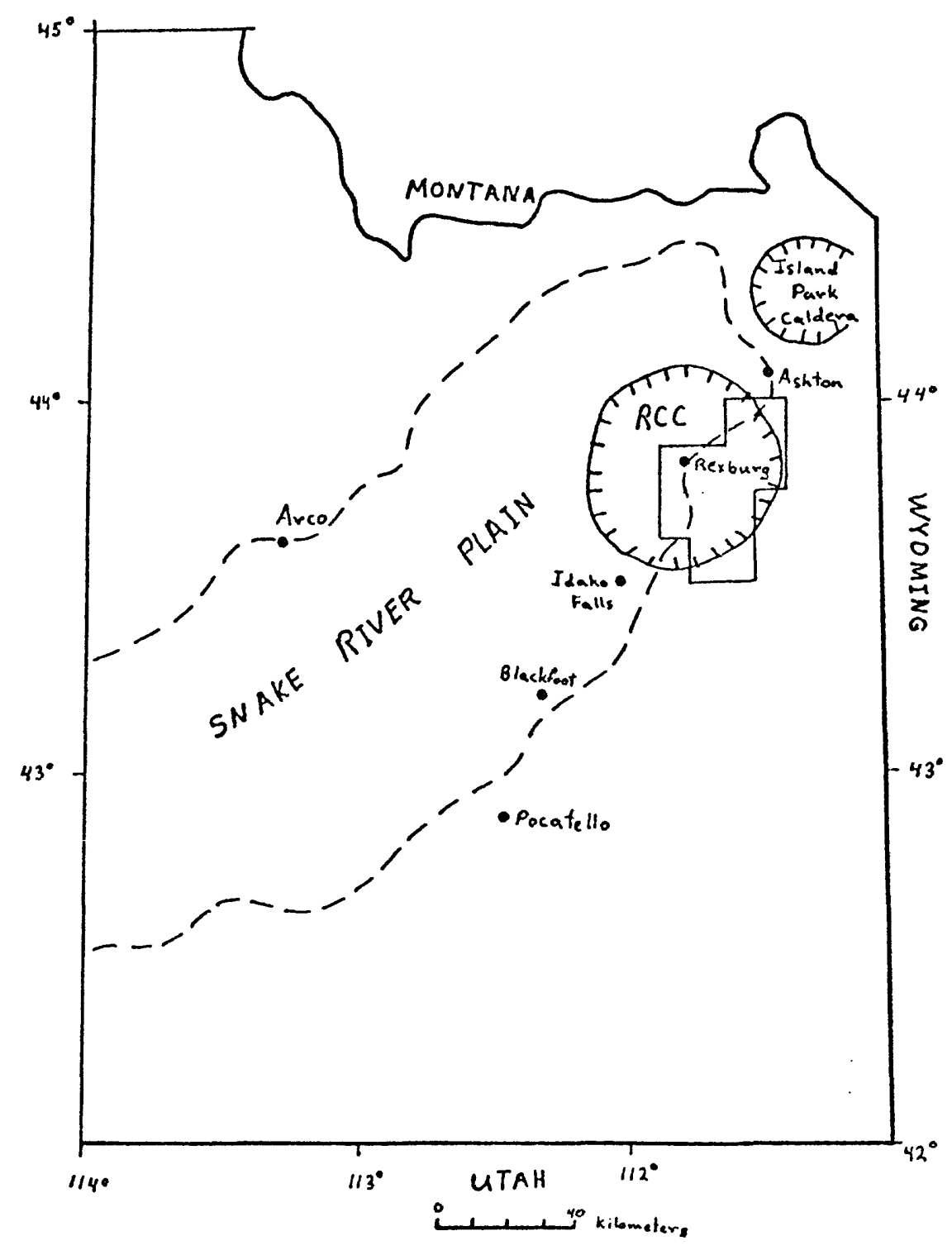

Figure 1.--Index map of southeastern Idaho showing the location of the Rexburg caldera Complex (RCC) and the area covered by plate 1 (stippled). 

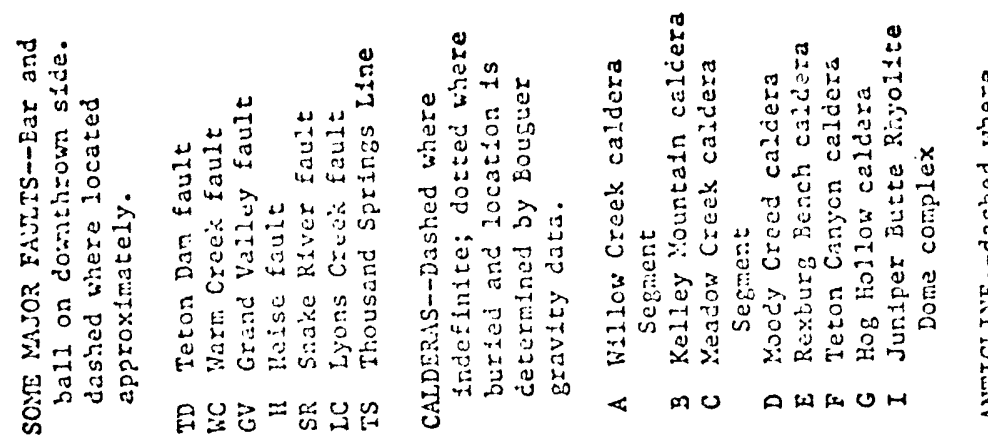

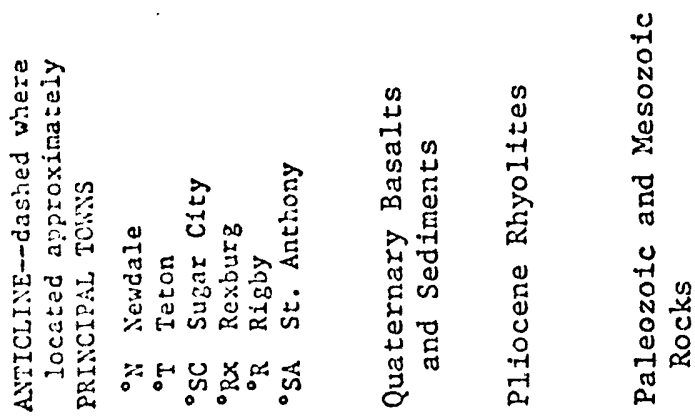

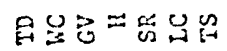
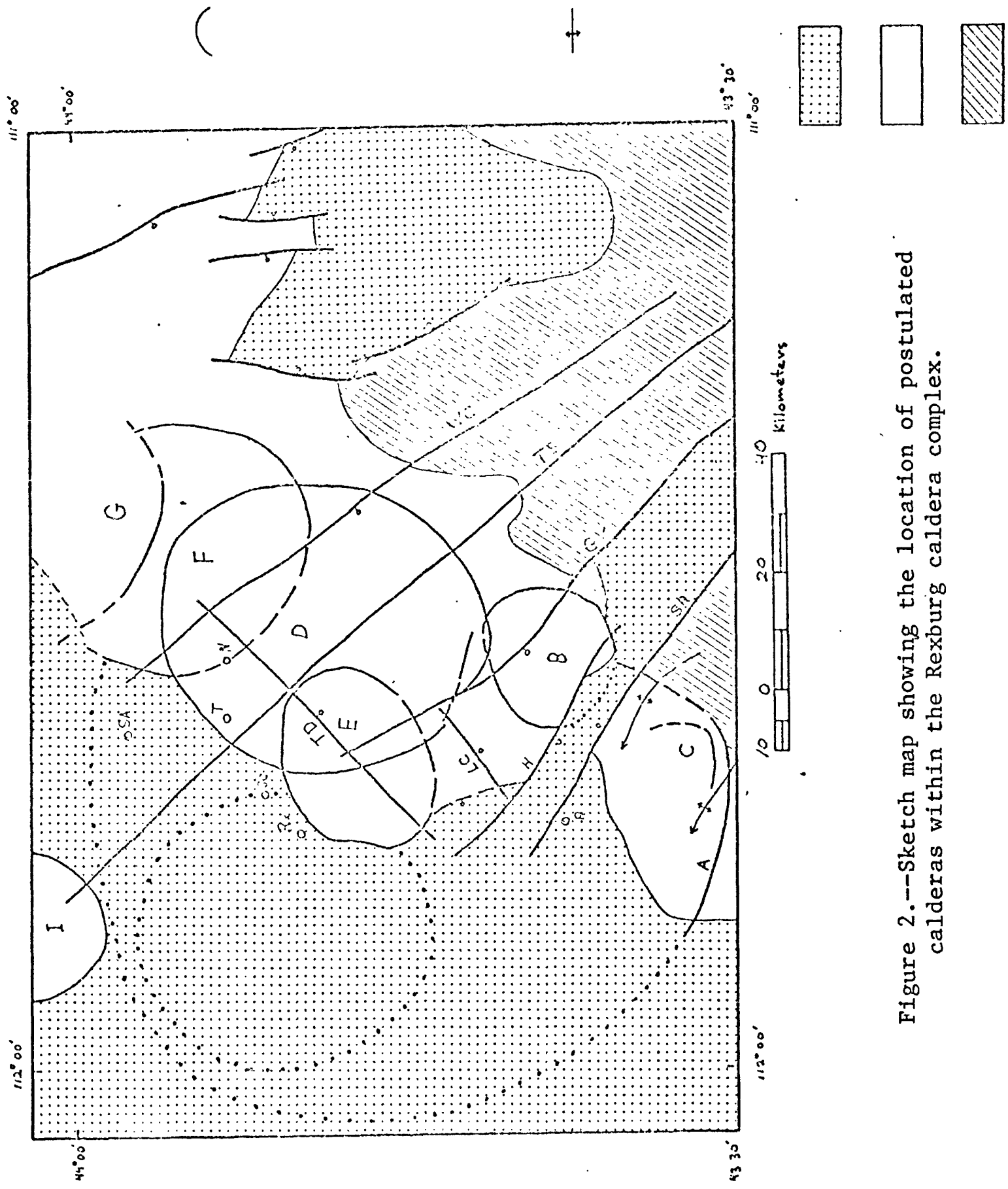
Geologic Setting and General Field Relations

The Rexburg caldera complex straddles the northeast-trending boundary between the eastern Snake River Plain and the Basin-Range province (fig. 1). The southern and eastern margins of the complex have been mapped across the foothills of the Caribou and Snake River Ranges and along the west side of the Big Hole Mountains. The western and northern margins, largely buried by basalt flows and clastic deposits of the Snake River Plain, have been determined primarily from gravity data (Mabey, 1978).

Detailed mapping and studies of directional features and facies in the volcanic units of the Rexburg caldera complex are still in progress.

The complex is a cluster of overlapping and nested calderas that were the sources of Pliocene rhyolite ash-flow and air-fall tuffs and lava flows. The principal structural features of the complex and adjacent Basin-Range structures are shown schematically in figure 2 .

The rhyolites of the Rexburg caldera complex unconformably overlie highly deformed miogeoclinal sedimentary rocks of Paleozoic and Mesozoic age that are well-exposed in the Snake River and Caribou Ranges, and in the Big Hole Mountains. These rocks have been described in detail by Staatz and Albee (1966). They are not discussed further in this report because they are not known to play an important role in the geothermal systems of the area.

The generalized stratigraphic and structural relationships of the pliocene volcanic rocks of the Rexburg caldera complex are shown in a schematic cross section from northeast to southwest across the best exposed part of the complex (fig. 3). The main features are: (a) onlap of successively younger units to the northeast, (b) repeated structural disruption of units older than the tuff of Heise, followed by (c) erosional beveling and widespread deposition of the tuff of Heise.

The rhyolites of the Rexburg caldera complex are unconformably overlain by locally derived tuffaceous clastic sediments and basalt lava flows and pyroclastic deposits and rhyolitic welded ash-flow tuff that has been correlated by R. L. Christiansen (written commun., 1976) with member B of the Huckleberry Ridge Tuff in the southwestern Yellowstone National Park region. The Huckleberry Ridge Tuff is K-Ar dated as $2 \mathrm{~m} \cdot \mathrm{y}$. old (Christiansen and Blank, 1972, p. B5). The northeast margin of the Rexburg caldera complex is overlapped by the Hog Hollow caldera, which is inferred to have been the source of a thin ash flow that is the uppermost part of the Huckleberry Ridge Tuff in this area, as discussed later in this report. Because of its younger age, the Hog Hollow caldera is not considered to be genetically related to the Rexburg caldera complex.

A variety of surficial materials is present; deposits of loess are especially extensive and conceal large areas of bedrock. 


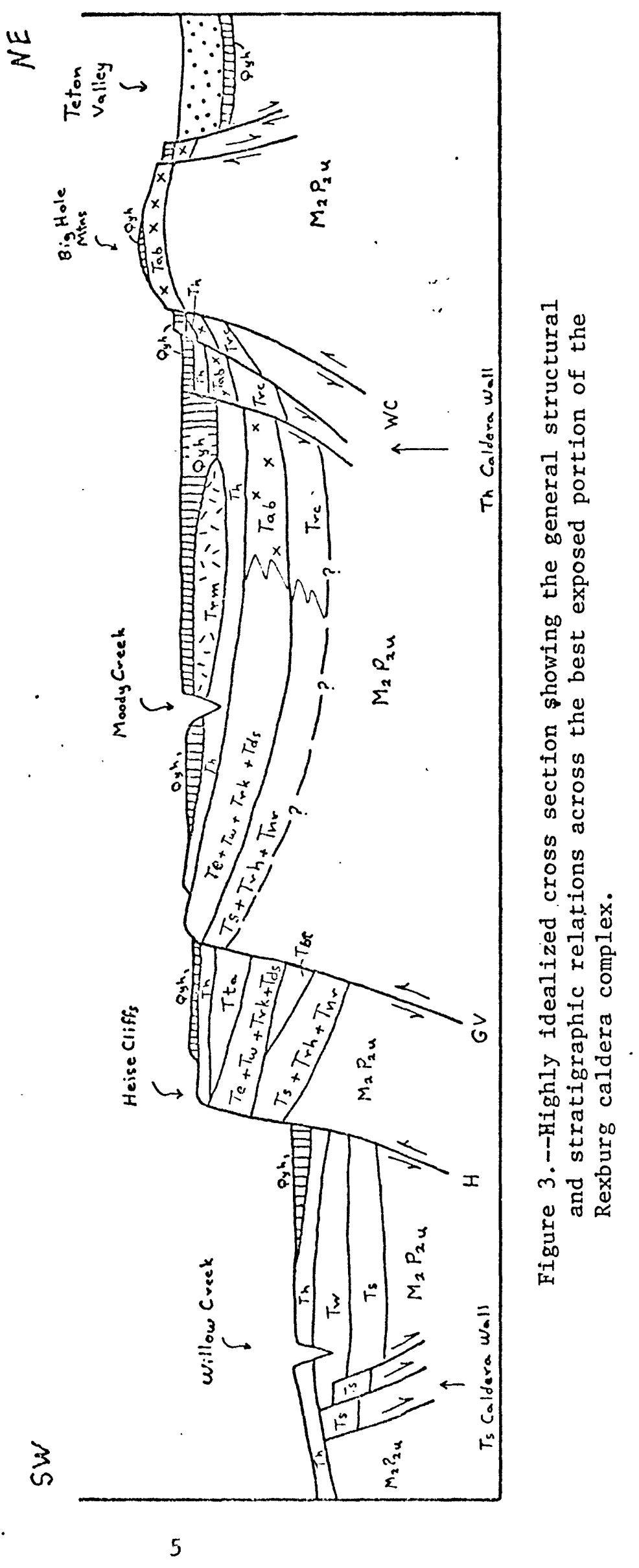




\section{Evidence for Caldera Locations}

In spite of the sparse exposures in much of the area covered by plate 1 , an attempt has been made to utilize available data to determine the location and extent of individual calderas within the Rexburg complex. It must be emphasized that the model presented is highly interpretive and subject to modification when further data is obtained. Such a model, however, will be a useful tool in the exploration for geothermal resources in the area. The following sections discuss the evidence used in inferring the caldera structures of the Rexburg caldera complex. Most of this evidence is shown graphically on plate 2.

Willow Creek Caldera Segment

The great thickness of the tuff of Spring Creek, south of the Kelley Mountain Dome (Sec. 9 and 10, T 3 N. R 41 E.) and in Willow and Meadow Creeks, suggests deposition within a caldera. A steep arcuate contact of the tuff of Spring Creek with Mesozoic rocks exposed in the valley walls of Willow and Meadow Creeks probably represents a portion of the caldera wall (pl. 1).

Kelley Mountain Caldera:

The tuff of Dora Springs and the rhyolite of Kelley Canyon are restricted to a roughly circular area approximately $10 \mathrm{~km}$ in diameter and centered just northeast of Kelley Mountain. With the exception of the northwest margin, these units are relatively well exposed ( 1 . 1 ). An inner convex and an outer concave break in slope are interpreted to represent warping of overlying units (especially the Huckleberry Ridge Tuff) over a scarp marking the northwestern boundary of the rhyolite of Kelley Canyon. This scarp may be either a fault scarp or simply the steep margin of the rhyolite flow, or it may be a combination of both.

The rhyolite of Kelley Canyon probably represents a rhyolite dome that postdates the collapse of the Kelley Mountain caldera (stage VI of Smith and Bailey, 1968), which formed along the ring fracture zone of the Willow Creek caldera. The tuff of Dora Springs underlying the rhyolite of Kelley Canyon suggests that collapse of the caldera occurred before the extrusion of the dome.

The Heise Fault and the Grand Valley Fault diverge around the Heise Dome ( $\mathrm{pl}$. 2). This is an example of a reactivated caldera structure forming a dome over a previous depression (see p.10). The course of the Snake River is semicircular and the river appears to have been diverted around this structure, accentuating its southern margin (p1. 2).

Meadow Creek Caldera Segment

A steeply dipping contact of the tuff of Wolverine Creek with the tuff of Spring Creek is exposed in Willow and Meadow Creeks. This 
contact is concentric to the Willow Creek caldera segment. The great thickness $(>90 \mathrm{~m})$ and coarse-grained nature of the tuff of Wolverine Creek in this area, and the presence of probable base-surge structures, indicate a nearby source and suggest that the steep contact may represent a segment of a caldera wall. The absence of the tuff of Wolverine Creek in the vicinity of Birch Creek may indicate that the buried caldera wall lies between Birch Creek and Meadow Creek.

Moody Creek Caldera

The Moody Creek caldera is a circular structure which is well defined by the following topographic and structural features (p1. 2): an arcuate topographic scarp northwest of Teton, interpreted as the northwest segment of the caldera rim; arcuate sections of the Teton River and Canyon Creek that delineate the north and northeast segments; arcuate sections of Canyon Creek and Calamity Creek that delineate the east segment; a concave break in slope that defines the southeast segment; arcuate sections of Moody Creek that delineate the south segment; and an arcuate fault scarp and an arcuate stream channel that delineate the west rim of the caldera. The western rim is accentuated because it coincides with the western limit of the basalt of the Lyons Creek-Sommers Butte rift zone. The basalt flows probably ponded against the caldera wall.

The northeastern margin of the caldera has apparently been broken by radial fauits, as is indicated by linear north- and northeasttrending portions of the Teton River and Canyon Creek channels that offset the arcuate segments.

The rhyolite of Long Hollow provides further evidence in support of a Moody Creek caldera. The south and east margins of this rhyolitic lava flow, which probably had a nearby source, appear to have been controlled by a steep arcuate scarp or caldera wall. This flow then, likely represents late stage ring-fracture volcanism (Stage VI) as defined by Smith and Bailey (1968).

Rexburg Bench Caldera

The southwest, west, and northwest margins of the Rexburg Bench caldera are marked by fault scarps, which define the boundary between the Rexburg Bench and the Snake River Plain. At the north edge of the caldera, the scarp grades into a concave break in slope that is also the boundary of the bench. The northeast and east margins of this caldera are defined by the arcuate channel of Moody Creek and by the contact of the basalt of Moody Creek with the Huckleberry Ridge Tuff. In this case, the center of the caldera was high because of reverse reactivation of the caldera rim faults (see p. 10), and basalt that erupted outside the caldera flowed against the upraised central area.

In addition to these features, which apparently delineate the margin of the Rexburg Bench calderá, there are several features within 
the caldera which may be related to its formation. Approximately $2 \mathrm{~km}$ inside the west edge of the Rexburg Bench caldera is a graben and an arcuate zone of major closed depressions (p1.2). To the north, the continuation of this line of depressions is marked by a convex break in slope. This break in slope probably reflects drag along the Rexburg Fault. The depressions may have resulted from the secondary collapse or sagging of pleistocene rocks into grabens related to drag and extension within the more brittle rocks beneath them.

Teton Canyon Caldera

The limits of the Teton Canyon caldera are very poorly defined, and it is the most questionable of all the caldera structures described in this paper. The following features appear to delineate the extent of the Teton Canyon caldera: the northwest margin is marked by a break in slope, an arcuate stream channel, and an arcuate pattern of contact between basalt of Moody Creek and the Huckleberry Ridge Tuff; the northeast margin is defined by a number of concentric, arcuate faults and arcuate sections of the Teton River channel east of the area included in plate 1 (Prostka and Hackman, 1974); the southeast margin is shown by the curvature of the generalized contours east of Canyon Creek; and the southern margin is marked by the edge of post-Huckleberry Ridge Tuff basalts, which apparently ponded against the inside of the caldera rim south of Highway 33, in the vicinity of Canyon Creek.

The extreme thickness ( $>100 \mathrm{~m}$ ) of the Huckleberry Ridge Tuff in the canyons of the Teton River and Canyon Creek, as well as the presence of lake sediments below the Huckleberry Ridge Tuff, suggest that a Pliocene caldera existed in this area.

Western Rexburg Caldera Complex

In addition to the preceeding geologic and geomorphic evidence, gravity data can be used to delineate the western margin of the Rexburg caldera complex (Mabey, 1978, fig. 1). This gravity map also indicates that another smaller caldera, similar to those just described, may be concealed beneath Snake River Plain deposits immediately west of Rexburg. The outline of this possible unnamed caldera is shown by a dotted circle on figure 2.

Drilling currently in progress in Sugar City has penetrated $>600 \mathrm{~m}$ of rhyolitic lava flows, as well as ash flow and air fall tuffs. This suggests a source in that area and supports the existence of the caldera defined by the gravity data.

Hog Hollow Caldera

In addition to the evidence for the multiple Pliocene calderas of the Rexburg caldera complex, there is a considerable amount of evidence to suggest that a small, early Pleistocene caldera may overlap the complex north of the Teton River. Evidence for this, the Hog Hollow caldera, is as follows: 
1) The presence of an arcuate depression known as Hog Hollow, the outer or south rim of which may mark the caldera wall if it is a reflection of a caldera moat.

2) A sharp monocline and normal fault system coincides with the inner rim of the Hog Hollow depression. These structures may have been produced by a combination of pre-collapse tumescence and post-eruption resurgent doming of the center of the caldera.

3) A thin ( $\sim 1-2 \mathrm{~m}$ ) welded tuff overlies the Hucklebery Ridge Tuff in the immediate vicinity of the Hog Hollow caldera and becomes thinner and more poorly preserved away fom the caldera.

4) Alteration of pre-Huckleberry Ridge Tuff basalts and gravels, local vertical pipe-like concentrations of calcareous cement within air fall tuffs, and veins of chalcedony and opal, indicate widespread hydrothermal activity in the area.

5) The distribution of the basalts of Moody and Canyon Creek against the Huckleberry Ridge Tuff suggests a large, gently sloping dome in the Huckleberry Ridge Tuff. The margin of this dome is roughly concentric with Hog Hollow and is located $8-10 \mathrm{~km}$ outside the caldera.

6) Secondary flow features in the Huckleberry Ridge Tuff may have been caused by tumescence of the precollapse dome. Small-scale secondary fiow structures as well as large-scaie northwest-trending overturned anticlines ( $120 \mathrm{~m}$ amplitude) and several northeast-trending lateral faults with up to $0.6 \mathrm{~km}$ of displacement are located in the southeast quarter of the Newdale Quadrangle and the southwest quarter of the Lindernan Dam Quadrangle. These large-scale structures apparently involved the tuff and the underlying clastic sediments, probably as deep as incompetent diatomaceous lake sediments upon which the overlying sequence moved.

7) A gravity anomaly (northeast corner of fig. 1, Mabey 1978) is coincident with the location of the Hog Hollow caldera rim.

Some of the above evidence is open to alternate interpretations. For example, the chalcedony and opal veins may have formed by degassing of the Huckleberry Ridge Tuff. The post-Huckleberry Ridge stream gravels in the Hog Hollow depression may indicate that the depression is an erosional feature. However, this would not explain the monoclinal flexure in the Huckleberry Ridge Tuff, the dikes, the large scale secondary flow structures, or the hydrothermal alteration of preHuckleberry Ridge units. Thus, although individual lines of evidence may not be conclusive, collectively they strongly suggest the existence of a caldera, the southern and southwestern margins of which are marked by Hog Hollow. 


\section{Structure of Upper Cenozoic Rocks}

The Rexburg caldera complex straddles the boundary between the Eastern Snake River Plain and Basin-Range provinces that developed contemporaneously in late Cenozoic time.

The southeastern boundary of the plain is characterized by mostly northeast-trending normal faults and associated warps and tilts, downthrown to the northwest. Also present are antithetic faults of lesser displacement, which are downthrown to the southeast. The best example of such an antithetic fault is the subsurface "inferred fault" of Prostka and Hackman (1974) that is called the Teton Dam Fault in this report because it extends close to the north abutment of the Teton damsite. Evidence for this fault includes well data from Haskett (1972), some evidence of minor post-Huckleberry Ridge movement northeast of the Teton damsite, and geophysical evidence (Zohdy, and others, 1978, fig. 2). The Lyons Creek Fault is another example of an antithetic northeast-trending fault. The northeast extension of this fault may be represented by a fault with the same direction of displacement, which appears to truncate the east end of the Hog Hollow caldera. A third example of a northeast-trending antithetic fault may be represented by a linear topographic scarp in the flood plain of the Snake River, extending southwest from St. Anthony ( 1.2$)$.

The Basin-Range structures are mainly northwest-trending horsts and grabens that are tilted to the northeast. Structural relief diminishes northwestward almost to zero near the edge of the plain. On the plain, normal faults that cut basalt have only small vertical displacements but there are many open fissures and rift zones that have accomodated regional extension. The principal northwest-trending faults of the study area are the Warm Creek fault zone, the Grand Valley Fault and its continuation across the Rexburg Bench as a basaltic volcanic rift zone, the Heise Fault, and the Snake River fault (fig. 2 and pl. 2).

In addition to these mapped faults, the Thousand Springs line (fig. 2) may represent a significant deep seated structural feature in this area. Thousand Springs Valley trends northwest and lies at the junction of the Snake River and the Big Hole ranges. A projection of this junction line to the northwest bisects the Moody Creek caldera and extends through Juniper Butte, another rhyolite eruptive center on the northern edge of the Rexburg caldera complex (M. A. Kuntz, oral communication, 1977).

Many of the overlapping and nested calderas of the Rexburg caldera complex are located at intersections of major northwest-trending and inferred northeast-trending faults, or are alined along major fault zones (fig. 2). This suggests that the rise of rhyolitic magma was guided to a large extent by zones of structural weakness along extensional faults. From the end of the Pliocene to the present, basalt has erupted through the complex from numerous vents, many of which are localized along northwest-trending fault zones. These eruptions were 
concurrent with regional extension. A small volume ash-flow that may have been erupted from the Hog Hollow area, is the only rhyolite known to have erupted in or near the Pliocene Rexburg caldera complex during the Pleistocene.

The present day warps and domes of the Rexburg caldera complex do not seem to be the result of rhyolitic intrusive doming, although resurgent doming may have occurred during the Pliocene; they were probably produced by differential subsidence during regional extension, after the rhyolite complex had solidified. This post-caldera regional extension reactivated older Basin-Range faults and also utilized arcuate caldera-related faults. Stocks and dikes of intrusive rock, presumed to be present beneath the caldera centers, and ring fracture zones may have strengthened and supported many of these areas during regional extension so that they have remained structurally and topographically high relative to the less well-supported terrane that sagged around them. The Heise Dome or Kelley Mountain caldera, and the Rexburg Bench caldera (p1. 2 and fig. 2), a gentle north-northeast tilted dome, are examples of highs that were possibly produced by this differential subsidence.

In other cases, extension and down-dropping of the Snake River Plain has taken advantage of the northwest and southeast segments of the caldera ring fracture zones. Thus, as is the case with the Moody Creek and Teton Canyon calderas, the northwest caldera-rim faults have been reactivated in such a way as to have dropped the northwest rims relative to the old caldera floors. Reactivation of the southeast caldera-rim faults, on the other hand, has continued to drop the center of the calderas relative to the southeast rims. This explains how the pleistocene basalts have flowed around the outside of the northwest margin of the Teton Canyon caldera and ponded on the inside along the southeast margin ( 1 1. 1).

Because of the high rate of regional extension in this area during the last $2.5 \mathrm{~m} \cdot \mathrm{y} \cdot$, many of the reactivated structures of the Rexburg caldera complex have significantly deformed the overlying younger clastic sediments, basalt, and Huckleberry Ridge Tuff. Caldera outlines have been impressed upward through the cover of younger rocks, and parts of their traces can now be seen on aerial photos and on the new detailed maps of the area (p1s. 1 and 2). However, because of the dominant influence of the northwest-southeast extension related to the formation of the Snake River Plain in this area, the northwest and southeast margins of these calderas are easiest to detect through the Pleistocene cover. In cases such as the Moody Creek and Teton Canyon calderas, the southwest and northeast margins are considerably disrupted by northeasttrending faults or are not tracable at all beneath the younger cover.

\section{Geothermal Overview}

Several geologic features of the Rexburg area suggest possible geothermal potential: 
1) Favorable combination of hydrology and structure--High precipitation in the mountains recharges the groundwater system which discharges into the Snake River aquifer. The Rexburg caldera complex is ideally situated to intercept groundwater flow and channel it downward along fault zones where it may be heated and stored in closed-basin reservoirs related to caldera subsidence and/or Basin-Range type structure.

2) Favorable tectonic environment--The continuing high rate of tectonic extension reactivates old faults, many of which are likely channelways for circulating geothermal water, breaking up sinter deposits and keeping the geothermal system unclogged.

3) Favorable thermal environment--High regional heat flow of Snake River Plain and Basin-Range provinces (Sass and others, 1976), augmented by Pliocene and Pleistocene rhyolitic volcanism and continuing Quaternary basaltic volcanism that have facilitated transfer of mantle heat to high crustal levels.

The structural setting of the principle occurrences of warm and hot water in the area of Rexburg caldera complex are summarized below:

1) Heise Hot Springs and Elkhorn Warm Springs--These two springs are located at the intersection of the northwest-trending Heise fault zone with northeast-trending faults. Heise Hot Springs is also near the rim of Kelley Mountain caldera.

2) Pincock Hot Springs--Also known as Green Canyon Hot Springs. Located at the intersection of the northwest-trending Warm Creek fault zone and the ring fracture zone of the Moody Creek caldera.

3) Newdale Thermal Anomaly (Brott and others, 1976)--Is roughly coincident with the area circumscribed by the overlap of the Moody Creek and Teton Canyon calderas, and the northeast-trending Teton Dam fault.

4) Teton--A northeast-trending area of hot and warm water around the town of Teton is located on or near the northwest section of the Moody Creek caldera ring fracture zone.

5) Rexburg Bench--A north-trending arcuate zone of closed collapse depressions south of Rexburg is traceable eastward as a break in slope on the bench. It has warm water wells along it, with higher temperatures reported along the two intersections of this arcuate zone with the northeast-trending Teton Dam fault. High heat flow has been measured by Blackwell (Brott and others, 1976) along this fault.

The distribution of hot water from wells and springs in the Rexburg area is concentrated along major late Cenozoic linear and arcuate fault zones, and especially at the intersections of these zones. Maps showing contoured reservoir temperatures calculated from the water chemistry also show a possible concordance with major structures (R. Stoker, oral 
commun., 1977). Other intersections of major structures may also have geothermal potential, despite the lack of shallow indications of hot water. There is insufficient subsurface information to evaluate the extent to which cold ground water perched at high levels may conceal underlying geothermal systems.

Closed circulation in structural basins, of either Basin-and-Range type or caldera origin, combined with the tapping of deep heat sources via water circulation along major faults are conditions. favorable to the formation of a geothermal resource. Thus, the most promising locations for geothermal exploration in the Rexburg Bench area may be where two calderas overlap, resulting in a maximum depth of fill and intersecting fracture or fault systems. The northeast-trending normal faults antithetic to the Snake River Plain may also have special geothermal significance because they interrupt plainward migration of ground water and provide channelways for water to descend to hot depths. In support of this concept, it should be noted that a major gravity low 1ies southeast of the Teton Dam Fault within the overlap of the Rexburg Bench and Moody Creek calderas suggesting a maximum thickness of low density rocks. A similar low is located within the overlap of the Moody Creek and Teton Canyon calderas. 


\section{References}

Brott, C. A., Blackwel1, D. D., and Mitche11, J. C., 1976, Heat flow study of the Snake River Plain region, Idaho, in Idaho, Part 8: Idaho Dept. of Water Resources Water Infor. Buil1. No. 30, $195 \mathrm{p}$.

Christiansen, R. L., and Blank, H. R., Jr., 1972, Volcanic stratigraphy of the Quaternary Rhyolite Plateau in Yellowstone National Park: U.S. Geological Survey Prof. Paper 729-B, p. B1-B18.

Haskett, G. I., 1972, Ground-water geology of Rexburg Bench, Idaho: U.S. Bur. Reclamation, Adm. Rept., 21 p.

Mabey, D. R., 1978, Gravity and Aeromagnetic Anomalies in the Rexburg Area of Eastern Idaho: U.S. Geological Survey Open-File Report 78-382.

Prostka, H. J., and Hackman, R. J., 1974, Preliminary geologic map of the NW $1 / 4$ Driggs $1^{\circ}$ by $2^{\circ}$ quadrangle, southeastern Idaho: U.S. Geological Survey Open-File Report 74-105.

Sass, J. H., Diment, W. H., Lachenbruch, A. H., Marsha11, B. V., Munroe, R. J., Moses, T. H., Jr., and Urban, T. C., 1976, A new heat-flow contour map of the conterminous United States: U.S. Geological Survey Open-File Report 76-756, $24 \mathrm{p}$.

Smith, R. L., and Bailey, R. A., 1968, Resurgent Caldrons, in Studies in Volcanology, Coats, R. R., Hay, R. L., and Anderson, C. $\bar{A}$., editors: Geol. Soc. Amer. Memoir 116, p. 613-662.

Staatz, M. H., and Albee, H. F., 1966, Geology of the Garns Mountain quadrangle, Bonneville, Madison, and Teton Counties, Idaho: U.S. Geological Survey Bul1. 1205, 122 p.

Zohdy, A. A. R., Bisdorf, R. J., and Jackson, D. B., 1978, Simple "Total Field and Schlumberger Soundings Near Sugar City, Idaho: U.S. Geological Survey Open-File Report 78-709. 